\title{
CLINICAL STUDY ON THE RELATION BETWEEN THE CHRONIC TONSILLITIS AND LIVER FUNCTION
}

Report 3 Effect of tonsillectomy on liver function

By

Y. KUMAGAI

\author{
From the Department of Oto-Rhino-Laryngology, School of Medicine \\ Kumamoto University. (Director: Prof. Y. Nosaka)
}

Effects of tonsillectomy upon the liver function were ovserved in 26 patients with chrcnic tonsillitis accompanied with dysfunction of the liver.

In 11 out of the 26 cases the liver function was restored to normal after tonsillectomy. It was probable that the dysfunction of the liver in these cases had its primary foci in their tonsils and therefore such favourable effects were brought about by the exstirpation of the tonsils together with an improvement in general condition which was a result of the exstirpation. This probability was sustained also by the fact that a relief in a subjective symptom, headache, which is one of general toxic symptoms, was more remarkable in the improved group as compared with the un-improved group. The effect of tonsillectomy was more favourable in male and younger patients, and the shorter the history of chronic tonsillitis, the more fanourable results were obtained by the operation. With regard to the shape and weight of the tonsils, degree of the projection, size and depth of the supratonsillar fossa, whether plug, mucus and pus were present or not, no particular differences could be found between the improvd and the un-improved group. Of all metabolic functions of the liver, the improvement of the proteometabolic function was most remarkable after tonsillectomy.

\section{慢性扁桃炎と肝㙨能との関連性に就ての臨床的研究}

\section{第 3 編 扁桃剔出の肝機能に及ぼす影響}

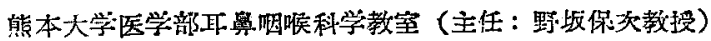

熊谷良良导

目次

緒 言

I実跧材料全びに方法

日実驗成䋹

III総括並びに洘按

維证 諭

\section{緒 言}

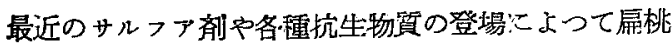
つ炎正は以前心較べると非常に抑制し得るようになり， こめに扁桃剔出の必要性の減退を述べる人もむる。文米

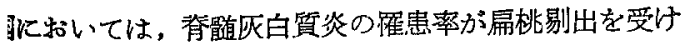

た者に多いことから種くの誵争が行われ，最近の手術は かなり频くなつたと云われている。しかし今日の化学潦 法，抗生削の劇的效果む炎淀を終媳に尊く迄には至ら

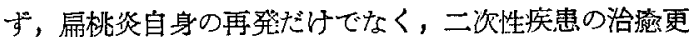
にはその発定る末然に防止する屚桃剔出の效果に比べる 可くもない事は当然である。

第1 編に括いては师機鋯の多相性より扁桃の慢性炎定

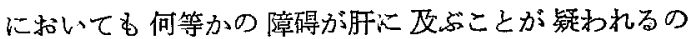
でこれ等について検查を行い，埾度ではあるが $26.0 \%$ に腅機能障碍のあることを迹べた・そこでこれ等の肝機 能障碍が果して扁桃に由来するむのであるか否かを見る 
ために，第2 編に拈いては Aktivitătdiagnostik とし て種々ある中より普通一般に用いられている超短波諘発 法を行い検索したが，他の病巣感染症程に有意の結論は 見出し得ず，これは肝の生理的機能あるいは他の何等か の因子に依るためであるらと推論した。しかし Fokus・ aktivität に反応しなかつたからとて直に扁桃性のもの でないと云らことはできない，他の扁桃性二次性疾患に おいても誘発刺皒には何等反応を示さず，又は単なる慢 性扁桃炎との問に有意の差を見出し得ないにも抱らず扁 桃剔出に依り效果を認める場合る歷々あり，更に二次性 疾患が相当進行している場合には原病栄とは既火関連性 を失っている場合も考えられる・そこで原巣病の疑いが ある場合扁桃剔出を行い，それ心依つて二次性疾患が軽 快あるいは治癒すればその扁桃は一応原病栄であらだと 判定し得る. 現在の所確実な診断は, 扁桃剔出化传る二 次性疾㭧の治癒を確めて決ぬる所の Diagnosis exjuvantivus より以外にないようである。

そこで私は本編においてては，第 1 編で述べた同症例に 扁桃剔出を行い，術後の肝機能の变動之経過日数，扁桃 の型状, 重量, 扁桃炎経過年数, 患者年令等との関連性 に就て検討を行つた。

\section{1. 実験材料並ひに方法}

第 1 編で述べた 肝機能障碍 26 例及び 機能障碍の無い 74 例に就て扁桃剔出後の遠隔成績を各険查法に依つて 術後10日より 18 ケ月迄追求した。

検查方法及び判定は第1編で述べた通りである。

\section{II. 実験成綪}

1. 術後の肝機能の 経過：機能障碍 26 例中術後正常 に復したものは11 例 (42.3\%)，低然として機能障碍の 残つたものは 15 例 $(57.7 \%)$ である。

2. 術後の 検查成績：（表 1) 障碍例の 扁桃剔出後に

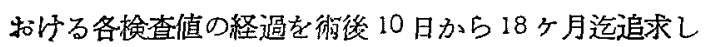
た成續は，全般的には高田反応 $R_{0} \sim R_{3}$, Gros 反応 1.68 cc, 昇永反灾 $0.68 \mathrm{cc}$, CCF-test $(-) \sim(+)$, 血清 Bilirubin 值 4.7 単位, BSP-test 5.2\%, 尿 Bilirubin 0 1.0 $\mathrm{mg} / \mathrm{dl}$, Urobilin 反応 $(-) \sim(+)$, Urobilinogen 量 $0.43 \mathrm{mg} / \mathrm{dl}$ ，馬尿酸試験 $51.78 \%$, Milon 反店 $(-) \sim(+)$ であり，これを更に恢復群に就て見ると高田反応 $R_{0}$, Gros 反応 $1.80 \mathrm{cc}$ ，戒祕反応 $0.74 \mathrm{cc}$, CCF-test $(-) \sim$ (+)，血清 Bilirubin 值 4.4 単位，BSP-test $4.3 \% ，$ 尿 Bilirubin O, Urobilin 反店 $(-)$, Urobilinogen 量 $0.29 \mathrm{mg} / \mathrm{dl}$ ，馬尿酸試験 $54.49 \%$, Milon 反応 (一) であ るのに対し，非恢復群では高田反忘 $R_{0} \sim R_{3}$, Gros 反応
第 1 表 拄概能媁碍例の扁剔前後の経過

\begin{tabular}{|c|c|c|c|c|}
\hline 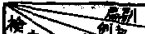 & 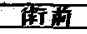 & \multicolumn{3}{|c|}{ 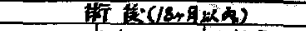 } \\
\hline$x=8$ & 26 & 26 & 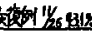 & 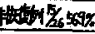 \\
\hline 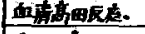 & $R_{0} \sim R_{m}$ & $R_{0} \sim R_{1}$ & $R_{e}$ & $R_{-} \sim R_{3}$ \\
\hline Groves: (ce) & 1.61 & 1.68 & 1.80 & 1.59 \\
\hline 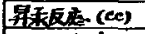 & 0.63 & 0.68 & Q.74 & 0.63 \\
\hline CCF-tost & $-\sim+t$ & $=\sim t$ & $-\sim+$ & $-\infty+$ \\
\hline 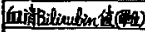 & 6.6 & 4.7 & 44 & 5.0 \\
\hline BSP-tat (\%) & 6.5 & 5.2 & 4.3 & 5.8 \\
\hline RBelindin (mote) & $0 \sim 10$ & $0 \sim 10$ & 0 & $0=1.0$ \\
\hline Golitin & $-\sim t$ & $-2+1$ & - & $-2+$ \\
\hline 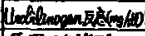 & 054 & 0.43 & 0.29 & 454 \\
\hline 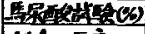 & 50.47 & 51.78 & 54.49 & 49.80 \\
\hline Milon E商. & $-a+$ & $-1+1$ & - & $--t$ \\
\hline
\end{tabular}

$1.59 \mathrm{cc}$, 昇我反応 $0.63 \mathrm{cc}, \mathrm{CCF}$-test $(-) \sim(+)$. 血清 Biliribin 值 5.0 単位, BSP-test $5.8 \%$ ，尿 Bilirubin O $\sim 1.0 \mathrm{mg} / \mathrm{dl}$, Urobilin 反応 $(-) \sim(+)$, Urobilinogen 量 $0.54 \mathrm{mg} / \mathrm{dl}$, 馬尿酸試験 $49.80 \%$, Milon 反応 $(-) \sim$ (+)である.

3. 扁桃上窩の梁さと術後の肝機能との関孫：(表2) 右扁桃に招いては，恢復群は $0.4 \sim 1.5 \mathrm{~cm}$ の範囲で平均 $1.0 \mathrm{~cm}$ であるのに対し，非恢復群では 0.5 1.5cm で平 均 $1.0 \mathrm{~cm}$ である。左扁桃炕おいては，恢復群は $0.4 \sim$ $1.5 \mathrm{~cm}$ で平均 $1.1 \mathrm{~cm}$ であるのに対し，非恢復群では 0.6 $\sim 1.4 \mathrm{~cm}$ で平均 $1.0 \mathrm{~cm}$ である.

\section{第 2 表 衡後の肝機能 $と$ 徧桃上简の} 深さ（平均）

\begin{tabular}{|c|c|}
\hline 古矤復利 & $0.4 \sim 1.5(1.0)$ \\
\hline 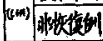 & $0.5 \sim 1.5 \quad(1.0)$ \\
\hline 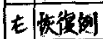 & $0.4 \sim 1.5 \quad(1.1)$ \\
\hline (im) & $0.6 \sim 1.4 \quad(1.0)$ \\
\hline
\end{tabular}

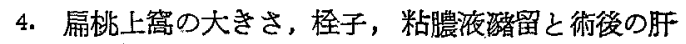
機能との関䐆：（表3）扁桃上窝の大なるるの6 例中恢 復 2 例，非恢復 4 例である．この中栓子及び粘膿夜を有 するもの 5 例及び 4 例で，恢復と非恢復は夫ょ 3 例之 2 例及び 1 例と 3 例である. 中等度のもの13 例中恢復 7 例，非恢復6 例である.この中柽子及び粘膿液を有する もの 7 例及び 5 例で，恢復之非恢復は夫ょ 5 例之 2 例及

第 3 表 衍後の肝㧴能と扁桃上㖹の 大きさ・栓子・粘膿液 $(\%)$

\begin{tabular}{|c|c|c|c|c|}
\hline 上㙏 & 洲则 & $N$ & 栓子 & 梗职 \\
\hline $\begin{array}{l}大 \\
6\end{array}$ & 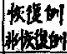 & $\begin{array}{l}2(33.3) \\
4 \text { (c6) }\end{array}$ & $\begin{array}{ll}3 & (600) \\
2 & (400) \\
\end{array}$ & $\begin{array}{ll}1 & (25 .) \\
3 & (75 .)\end{array}$ \\
\hline $\begin{array}{l}\phi \\
13\end{array}$ & 极姟利 & $\begin{array}{l}7(53,0) \\
6(46,2)\end{array}$ & $\begin{array}{l}5(714) \\
2(286) \\
\end{array}$ & $\begin{array}{ll}3 & (60.0) \\
2 & (41.0)\end{array}$ \\
\hline 小 & 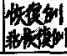 & $\begin{array}{ll}1 & (54.3) \\
6 & (85.7)\end{array}$ & $\begin{array}{ll}1 & (2200) \\
4(800)\end{array}$ & $\begin{array}{ll}2 & (5010) \\
2 & (500)\end{array}$ \\
\hline
\end{tabular}


び例と2 例である.小なるすの7例中恢復 1 例, 非恢 復6例こある，この中程子及び粘膿液を有するすの 5 例 及び 4 例で，恢復と非恢復は夫之 1 例と 4 例及び 2 例と 2 例である。

5. 痌桠の型状及び突出度之術後の 肝機能との関係： （表 4）球状型では障碍 11 例中恢復 5 例 (45.5\%) であ ク，【度の 4 例中 1 例， 四度の 3 例中 2 例， N 度の 2 例 中 I 例, V度の 1 例中 1 例である.䫘垂型では障碍 5 例 中恢復 1 例 $(20.0 \%)$ であり， I度の 1 例中 1 例である. 㾫平型では障䅞 4 例中恢復 2 例 $(50.0 \%)$ であり，I度 の3 例中 1 例， 伎度の 1 例中 1 例である. 弁状型には恢 復例は見られない，左右不同型では障碍 4 例中恢復 3 例 (75.0\%) である. 更にこれ等を全般の突出度別に見る と，I度では障碍 4 例中恢復 1 例，【I度では6 例中 3 例，四度では 8 例中 2 例，IV度では 2 例中 1 例，V度で は】例中 1 例である・V度には恢復例はない。

第 4 表 椸剔後恢復例と型状との関倸

\begin{tabular}{|c|c|c|c|c|}
\hline 型状 & \multicolumn{2}{|c|}{ 夜斡的制 } & \multicolumn{2}{|l|}{ 校往加 } \\
\hline \multirow{6}{*}{ 球状型 } & $\pi$ & 4 & 1 & 25.0 \\
\hline & III & 3 & 2 & 66.7 \\
\hline & $\bar{v}$ & 2 & 1 & 50.0 \\
\hline & $\vec{\nabla}$ & & & \\
\hline & $\overline{7}$ & 1 & 1 & 100.0 \\
\hline & & 11 & 5 & \\
\hline \multirow{4}{*}{ 㢣和 } & $\mathbf{I}$ & 1 & & \\
\hline & II & 1 & 1 & 100.0 \\
\hline & 西 & 3 & & \\
\hline & & 5 & 1 & 20.0 \\
\hline \multirow{3}{*}{ 雇平型 } & I & 3 & 1 & 333 \\
\hline & III & 1 & 1 & 100.0 \\
\hline & & 45 & 2 & 50.0 \\
\hline 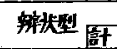 & III & 2 & & \\
\hline \multirow[t]{2}{*}{ E右不同整 } & & 4 & 3 & 75.0 \\
\hline & $I$ & 4 & 1 & 25.0 \\
\hline \multirow{4}{*}{ 凂計 } & II & $\frac{6}{6}$ & 3 & 50.0 \\
\hline & I & 8 & 2. & 25.0 \\
\hline & W & 2 & 1 & 500 \\
\hline & & $\frac{1}{1}$ & & \\
\hline
\end{tabular}

6. 晶桃の重量と術後の肝機能との関係：（表 5) 右 扇桃に就ては，恢復群では 1.5〜4.6g の箸囲で平均 $3.4 \mathrm{~g}$ であるのに対し，非恢復では 1.5 6.3g で平均 $3.3 \mathrm{~g}$ である・左扁桃に就ては，恢復群では 1.5〜 5.5g で平均 $3.0 \mathrm{~g}$ であるのに対し，非恢復群では 1.5〜6.1g で平均 $3.0 \mathrm{~g}$ である。

第 5 表 菦後の肝喽能と扁桃の重量（平均）

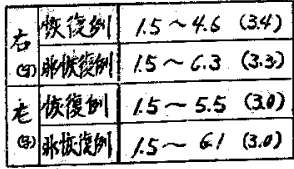

7. 自覚症状之術後の 肝機能との関係：（表 6）術前 の自覚症状の術後に就ける治癒率を見るに，習慣性アン ギー+ $88.9 \%$ ，頭痛 $75.0 \%$ ，㸶頭痛 $70.0 \%$ ，倦意感 62.5 $\%$ ，心悸昂進 42.9\%，肩凝り 33.3\%，咽頭乾燥感 33.3\%， 咽頭異物感 $80.0 \%$ ，督血 $25.0 \%$ ，発声障碍 $33.3 \%$ ，咽頭 王迫感 $50.0 \%$ ，咽頭灼熱感 100\%，食思不振 $100 \%$ の恢 復を見ている. 又術後の肝機能恢復群と非恢復群に打け る自覚症状の恢復率を比較するに，習慣性アンギーナは $87.5 \%$ と $80.0 \%$ ，項痛は $77.8 \%$ と $66.7 \%$,咽垻痛は 75.0 $\%$ と $66.7 \%$ ，倦㥐感は $80.0 \%$ と $33.3 \%$ ，山情昂進は $0 \%$ 之 $50.0 \%$, 局凝りは $66.7 \%$ と $0 \%$ ，咽頭乾燥感は $0 \%$ と $50.0 \%$ ，咽頭異物感は 0\%と $100 \%$ ，叠血は $25.0 \%$ と0 $\%$ ，発声障碍は $0 \%$ と 50.0\%，咽頭圧迫感は $0 \%$ 之 100 $\%$ ，咽頭灼熱感は 0\%と $100 \%$ ，食思不振は $100 \%$ と0 \%である.

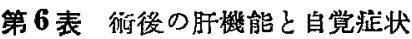

\begin{tabular}{|c|c|c|c|c|c|c|}
\hline 自党呈 & 慗 & & & & & \\
\hline 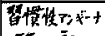 & & & $375 / 1$ & 0 & & 80.0 \\
\hline & 9 & $7 \mid 7$ & 17.8. & & & 66. \\
\hline & 4 & & 15.0 & & & 66.7 \\
\hline & 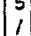 & 4 & & 6 & & $\begin{array}{l}33.3 \\
58.0\end{array}$ \\
\hline 裔㠜 & 3 & $2 \mid 6$ & 66.7 & 3 & & \\
\hline 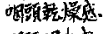 & 2 & & & & & 58.8 \\
\hline 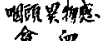 & I & & & 4 & & |110.0 \\
\hline 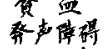 & 4 & & 25.0 & & & 50.1 \\
\hline & & & & & & Iteo \\
\hline 1895 & & & & & & 1820 \\
\hline & & & & & & \\
\hline
\end{tabular}

“8. 年令及び性別と術後の 肝機能との関係：(表 7) 全般的には機能障碍男 16 例中恢復 9 例，女 10 例中 2 例 である: 11〜20才では機能障碍 8 例中恢復 6 例 (75.0\%) (男6 例中 5 例，女 2 例中 1 例)，21 30 才では 15 例中 5 例 (33.3\%) (男 8 例中 4 例，女7例中 1 例) であるが， 31 才以上には男女共に恢得例は見られない。

第 7 表 肝機能恔楊管と年合及び性別

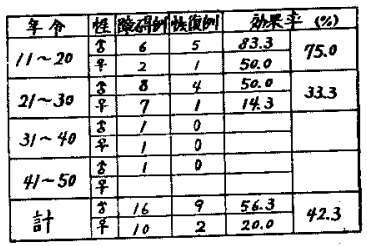

9. 術後肝機龍 恢復迄厄 要した 期間：（表 8）術後3 ヶ月以内に譏能正常となつたるの 2 例 (17.3\%)，6ヶ月 


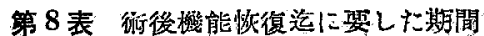

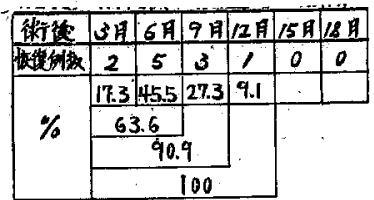

以内 5 例 $(45.5 \%) ， 9$ 月以内 3 例 $(27.3 \%) ， 12$ ケ月 以内 1 例 $(9.1 \%)$ である。

10. 肝機能障碍程度及び 扁桃炎経過年数之術後の訮

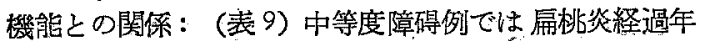
数 10 年以下欢 16 年以上には恢復例は見られない.11 〜15 年経過のむのに 1 例恢復を見るのみである.軽度障 碍例て性 5 年以下のもの6 例中 5 例 $(83.3 \%) ， 10$ 年以 下 7 例中 3 例 $(42.8 \%) ， 15$ 年上下 5 例中 1 例 (20.0\%) に恢復を見ているが，16年以上では1例の恢復も見ら れない.

第 9 表 启桃炎経過年数と恢復韯との関保

\begin{tabular}{|c|c|c|c|c|c|c|c|}
\hline$z$ & 扁剔 & －5年 & -104 & -154 & -20年 & $20+2$ & 不明 \\
\hline \multirow{3}{*}{ 中 } & 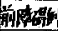 & & 1 & 1 & 1 & & \\
\hline & 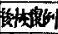 & & & 1 & & & \\
\hline & $\%$ & & & loan & & & \\
\hline & 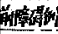 & 6 & 7 & 5 & 2 & 1 & 2 \\
\hline & 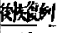 & 5 & 3 & 1 & & & 1 \\
\hline & $\%$ & 83.3 & 42.8 & 20.0 & & & 500 \\
\hline
\end{tabular}

11. 各梚查別の恢復率：（表 10）血清 Bilirubin'檤 が機能障䅞 17 例中 14 例 (82.4\%) の恢復を示し最も高 率である. 次いで Urobilin 反応 11 例中 8 例 (72.7\%)， 高田反度及び Milon 反応各 3 例中 2 例 (66.7\%)， CCF test 18 例中 11 例 $(61.1 \%)$, BSP-test 17 例中 10 例 $(58.8 \%)$, Urobilinogen 反店 21 例中 11 例 (52.4\%)， Gros 反応及び，馬尿酸試験各 11 例中9例 (50.0\%)，尿 Bilirubin 反応 2 例中 1 例 $(50.0 \%)$ ，景求反店 24 “例中

第 10 表 各検查别恢復登

\begin{tabular}{|c|c|c|c|}
\hline 极别 & 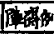 & 惔何的 & $\%$ \\
\hline 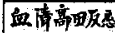 & $\mathbf{j}$ & 2 & 66.7 \\
\hline Gnos及 & 18 & 9 & 50.0 \\
\hline & 24 & $/ 1$ & 45.8 \\
\hline 血能Bindint & 17 & 14 & 82.4 \\
\hline CCF-test & 18 & 11 & 61.1 \\
\hline BSP-test & 17 & 10 & 58.8 \\
\hline 乐Bilinubin & 2 & I & 50.0 \\
\hline Unobilin & 11 & 8 & 72.7 \\
\hline Unobilinognes & 21 & $/ I$ & 52.4 \\
\hline 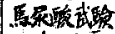 & 18 & 9 & 50.0 \\
\hline Anitonte & 3 & 2 & 66.7 \\
\hline
\end{tabular}

11 例 $(45.8 \%)$ の恢復率の順である.

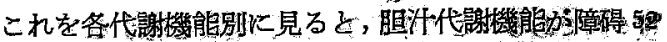

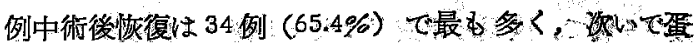

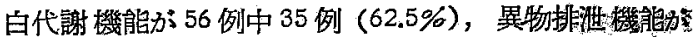
17 例中 10 例 (58.8\%), 解毒穖能加 18 例中9例 (50.0 \%) の順である。

\section{III. 総括並びに考按}

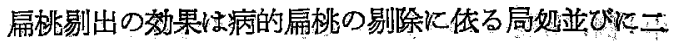
次性疾患の症状の 改善のみならず口蓋扁桃の 生理的谈

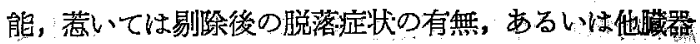

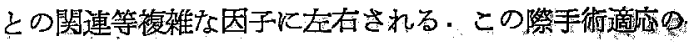

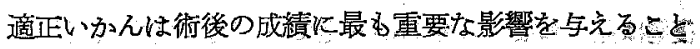
は勿論である。

孰玑にしても扁桃剔出效果の判定には術後の鼓隔成結 が正確な評価を与えるあのである.彷つてこれに闂する 調查報告は多い，しかし扁桃剔出の適店を決定するため。 種々の診断法が行われているにも抱らず未だ的礁なるの はなく，文扁䄻の形態的な面においても原病单としての 扁桃の形態的，生理的な面と二次性疾患との関連性に就 ての術前の検索報告は㕍々見る所であるが，これ等が屚 桃剔出後の遠隔成績との間にはいかなる関連を持つかと 云らことに就ての報告はそれ程多くはないようである.

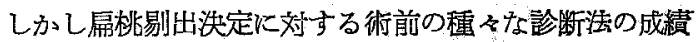
並びに二次性疾患と原病巣としての扁䄻の形態的特徽と の閝係等之同様に，扁桃剔出後に和るこれ等の成績か ら帰納的に考察検傠することす又重要である．この両者 の比較検討に㑈つてより確実な扁桃剔出の適応泆定を見 出し得るのではないかと思われる。

扁桃上外に病单と見做し得る病的部位もなくしかも屚 桃に病的所見を見出し，周期的の厎桃炎発来に低り二次

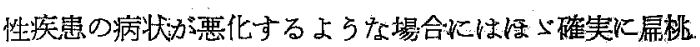

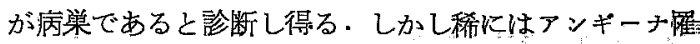
患の病麼むなく，屚桃炎の所見も不经暸であるが，瘇々

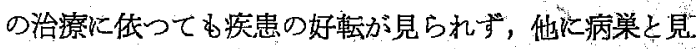
られる部位も無く，更に各種診断にも余り反応を見ない ものが，試みに行つた扁桃剔出に依り著效を収めること がありこれれ依り始めて扁䄻が原病单であうたと判期 することも尠くない、㕛これと反対に明かに扁桃分原病

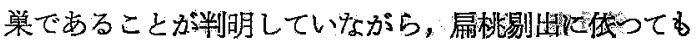
二次性疾患の治澺又は軽快を見ず，あるいは却つて堌悪 する例む見られる・私の症例では幸い術後堌悪の例は見 られなかつた。文術前肝機能障碍の有つた 26 例中術後 機能恢復の見られたるのは $42.3 \%$ であり，残りの $57.7 \%$ 
は依然として機能障碍が残存した，菊地も肝機能障碍例 D大多数汒術後機能正常化の傾向を示すと述べている． この正常化したものは一応扁桃が原病巣であり；これの 除去に依つて肝に好影響を及ぼしたことの他に，術前有

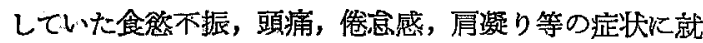
ても，術後食您の増進，頭痛消失等の好影響を与えてい る所加ら，扁桃剔出に依る全身状態の改善之相侯つて機 能の恢復が見られたものと考えられる・第 1 編に扣い て述へた如く神経学的に見ても，緒方，森本等は慢性碉 桃炎患者で術前植物神経系の異常を有していた者の大多 数は衍後正常に復したことを報告しているが，かつる植 物神経異常の改善が惹いては肝機能障碍の恢復に迄及几 たこことも想像される．更にこの他扁桃剔出そのものが つの Stress そなつて治㽷機転を促進するのではない かと思われる.このことに就ては堀口る刺㦸療法として 次の如く説明している．即ち扁桃剔出は最も多く習慣性 扁桃炎に対して行われ，事実扁桃剔出後咽頭炎の起る回 数は減少するのが常であるが，この場合試みに一側だけ 剔出を行い他側を残置して和いても，爾後習慣性扁桃炎 が全治することは時に経踰される所である．更に極端な 場合にはアンギーナに殆んど罹患したことの無い，乙か し風邪を引き易い小児に対して単に扁桃が大きいと云う 理由だけで扁桃剔出乃至切除，あるいはアデノイド切除 を行らことがあるが，このよらな場合に゙も風邪を引き易 い習慣は治痖することが多い，実際に执いても，単に口 盖扁桃が完全に取り除かれたと云うだけでは扁桃組織の

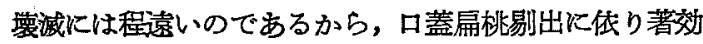
を収めたとしてるそれは単に原病巣を完全に除き得たと いら考え方たけでは説明できない，更に扁桃切除のみに 訨つても習慣性炎症の沿痖や，二次性疾患の治癒が営ま れる例を多く見ることがある：これ等の事から，扁桃剔 出は単に感染源として存在する咽頭における細菌の栄窟 を除去すると云うだけでは説明しきれない事象が数多く あると云らのである・又森本も微熱の患者で一側の扁桃 剔出のみで霆々平熱に復する事があると述べている事か らしても，扁桃剔出が一つの刺皒療法であると云う考觉 るある場合沉は首肯し得るようである・しかし術後も依 然と乙て機能障碍の残つた例は菊地，佐藤等も云ってい る如く，肝障碍が一㳄的のるのであつたか，あるいは 扁桃性のものであつたにしてる長期間のうらに二次性疾 患か涸定化され，非可逆性となり，原病栄の剔出に依つ ても遂に恢復を見ることができなからたものと思われ る.
障碍群の術後機能恢復は3〜6 ケ月の間に 正常化した 例が 45.5\% で最も多く，その他は期間の減ずるに徉い

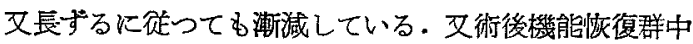
63.6\%は6ケ月以内に正常化して括り，更に9ヶ月以内 には 90.9\% と大多数が 正常化することが知られる . 即 ち機能障碍群で術後 1 年以内に正常に復しないものは最 早恢復の望みはないようである。これ性他の扁桃性病栄 感染疾患の治瘉江要する期間に較べるとや〉長いようで あるが，種々の因子の影響を蒙り易い肝の生理的機能に も関係可るのではないかと考光られる。

さて扁桃の形態面から観察するに，扇桃上简の梁さは 左右共, 恢復群, 非恢復群共飞 $1.0 \mathrm{~cm}$ 内外であり, 特 に美は見られない，又上窝の大きさ，栓子，粘膿液の猪 留等に就て見ると，上䈑の中等度のものが最も恢復率は 良好であり，小なるすのが最も低いが，恢復率之非恢復 率就て見ると上筒の大なるものと小なるるのには恢復 率がや〉䝵く，中等度のむのでは大差がない，栓子を有 するものでは扁桃上简の大なるすのと，中等度のもので は恢復群に柽子を有していたものが多く，小なるもので

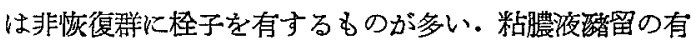
無に就ては扁桃上窝の大なるるのでは非恢復群に，中等 度のものでは恢復群に粘膿液を有していたものが多く見 られる．满上は扁桃の肉眼的所見と術後の経過を雉察 し，経過良好群比执いては扁桃は埋没性て栓子多く，不 変群では揕く，埋没性と栓子多数に意義があると述べて いる. 本実験では全般的には桎子を有するむのは恢復群 で 9 例, 非恢復群で 8 例, 粘膿夜は 6 例と 7 例であり, これ等に就て肝機能の恢復群之非恢復群との間には㭙別 の傾向はないようである。

扁桃の型状正び突出度と恢復率との臨保化就ては，左 右不同型の $75.0 \%$ が最も 高率であるが，この型状は各 型状の組合さつたるのであるために余り特徽づけること はできないそ他の型状では扁平型の 50.0\%が高く， 弁状型の0\%が最る低い，溝上は理没性で突出度の小な る症例に経過良好群が多く意義があるとしているが，本 実験ではかつる著鹏な傾向は認められず，又各型状別の 突出度に就て見てる同様である. 全体の乫出度に就ても V度の $100 \%$ の恢復率が最も高いが，これは例数が勘い、 ことも原因していると思われる。その他の各突出度に就 ても恢復率之の間に特別の関係は見出し得ない，術前の 成績では一般に埋没性て萎縮状のものに障碍群を多く見 たが，術後この型状，突出度に最も多くの沿痖又は軽快 が見らるれば手術前後の成顜よりして型状，突出度と二 
次性垁患との間に何等かの特微を㨔又得ると思らが，尠 く共本肝機能に関してはかつる点では余り特異的な面は 見られないようである・しかし前にる述べたように。こ れには二次性疾患の固定化あるいはその他の因子が眀係 していることも教光られ，直らに結論つけける事はできな いようである。

自覚症状の経過は術後アンギーナに霍患しなくなつた 者が $88.9 \%$ と高い改善率を示し，これは野坂教授，佐 藤, Stamberger, Fischer, Zabel 等も諗めている所で ある. その他咽頭異物感，咽頭痛等も70〜80\% と顕著 な恢復が見られる。咽頭枃热感，食思不振は $100 \%$ 恢復 率を示しているが，これは例数が数いことにす閏係する 亡思われる．次に術後肝機能の恢復の有無と自覚症状と の関係を見ると，第 1 編で述べた潜在性肝機能障碍時に

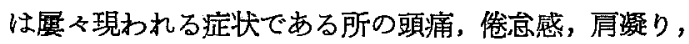
食思不振等は術後孰れも肝機能の不変群に較べ恢復群に これ等の症状の恢復も良好であるのが認められこれは 扁䄻剔出に依る全身状態の改善と共に，特に一連の全身 中毒症状と考えられる食照不振，頭痛等の恢復の著しい ことは肝解機能改善の一嘊候とも見られる。

㙨能唡查に就て見ると術後は全般的にや〉改善の傾向 が見られる・文备検查値に就ては CCF-test では術後 の恢復群，非恢復群の間に殆んど美は見られない，しか し优の各検查では両群の間に幾分差異か認められ，しか も恢復群での平均値に熟れも正常範囲内に復している。 更に 各検查別の恢復率に就て 見ると，血清 Bilirubin 值, 尿 Urobilin 反応, 高田反応, Milon 反応等の恢 復が良好である.これ等は術前の障碍程度が非常に軽度 であつたつめ扁桃剔出に依る局所的並びに全身状態の改 善に依り，容易に正常域值に恢復したものと思示れる。

次にこれ等を各代謝機能別に術後の恢復状況に就て見 ると，胆汗代謝機能の $65.4 \%$ が最高であり，異物排泄 㝊び解毒機能では低い、これは第 1 編において述べた如 く，後者の二機能に属する検查法性比較的各種の肝疾患 に共通で资患別特暴性が無く，しかも鋭敏な方法である ために術前の检查で障碍率が最る高く現われることや， 页は術後も他の諸検查では陰性となるような程度の障碍 が残存している場合にも, その非特異的鋭敏性のために 陽性を示す等の原因のためにこれ等両機能の恢復率が低 いものと思われる：これに文して胆汗代謝機能の恢復率 が良好であるのは，血清 Bilirubin 値，尿 Bilirubin 及び Urobilin 反応の異常が正常範囲を僅に超えた極め て軽微のものであり，容易に正常域値内え復したつめに
全般的の恢復率む高くなつたものであろう。

恢復率と年令及び性との関係に就ては，全般的には男 が $56.3 \%$ ，女かi $20.0 \%$ の恢復率を示し，男が 2 倍以上 を占めている. 年令別では $11 〜 20$ 才で男 83.3\%，女 50,0 $\%$ ，全体で $75.0 \%$ と最子高い恢復率を示し，31 才以上 では1例の恢復む見られないことは注目に值する・文扁 桃炎経過年数と恢復率との閸係を見ると，経過年数 5 年 以下のむのでは 83.3\%の恢復率となつているが，それ より経過年数の長くなるに従い恢復率は減少し，16年 以上経過群では 1 例の恢復も見ていない. 以上の扁桃炎 経過年数及び年令と術後の恢復率上の関係から考えて， 可及的早期に年令の若いらち，即ち二次性疾患の病变が 可逆性であるらちに原病栄の剔出を行つてこそ充分な好 果を挙げることがでさるのである.他の扁桃性病策感染 症に和いて子佐藤, 猪, 堂野前等も自験例及び女献例か ら原病巣の早期剔出の必要性を説いている. 溝上も扁桃 性病巣感染症の扁桃炎経過期間を術後の経過度好群と不 変群とに就て比較すると良好群の方が遥に短い、しかし 1〜2 年を経過した症例にあつてる引続き症状の固定し たすのではなく，扁桃炎に際し症状の増悪又は再発を綝 返していたるのは経過良好である。これに嚆し不变群で は長年月に亘りは5症状の固定していたすのに多いと述 べている、根尾も扁桃炎の合併症は早期の扁桃剔出に依 つてこれを予防し，その病状を軽減させ得ることを実験 的に明かにしている。しかし乍ら若年で早期にとは云 之，最近我が国でも漸次行かれつつある小览期の扁桃剔 出では全身麻醉に依る偶発症等も考慮に入れて検討しな ければならないのは当然のことである。

\section{結 猃}

慢性扁桃炎を有する者で肝機能障碍のある26 例とこ れを有しない74 例に就て扁桃剔出後の旰穖能を検討し； これと扁桃の型状, 突出度, 重量, 扁桃炎経過年数，年 令，性，自覚症状等との関連性を比較検討し，次の結論 を得た。

1. 肝機能障碍 26 例中術後 機能正常となつたものは 11 例 (42.3\%) であり,これは一㐫扁桃が原病巣である と考えられ，原病伹としての扁䄻の剔出と，それに依る 全身状態の改善と相俟つて好結果をるたらしたものと思 われる. 術前機能障碍の無い症例で術後機能の悪化した 例は認めなかつた。

2. 扁桃上简の樑さ，大きさ，烃子及び粘膿液猪留の 有無, 剔出扁桃の重量等に就ては, 機能恢復群としから ざるむのとの間に特異的関俰は見出し得ない. 
3. 扁桃の型状及び突出度と恢復率との間には特別の 傾向は無い。

4. 性別では男性に恢復率が良く，年令別では若年者 が高令者に較べ良好である. 又扁桃炎経過年数の短い程 絬果は良好である・即ち病栄感染症の疑いのある症例で は可及的早期淿だ二次性疾患の陳旧固定化の見られな い間に扁桃剔出を行うべきである。

5. 扁桃剔出に依る肝機能恢復に要する期間は 1 年以 内である. 1 年以上経つてなお機能障碍の残存するもの
は肝機能障碍が一次性のものであつたか，又は二次性の ものであつたにしても既估固化学れたものであり，洽 䄖は難しいと思われる。

6. 各検查別恢復率では血清 Bilirubin 值 $(82.4 \%)$, 尿 Urobilin 反応 $(72.7 \%)$ ，高田反応及び Milon 反応 (66.7\%) が比較的良效であつた。

代謝機能別の 恢復率では 胆汗代謝機能の $65.4 \%$ が最 あ高率であつた。

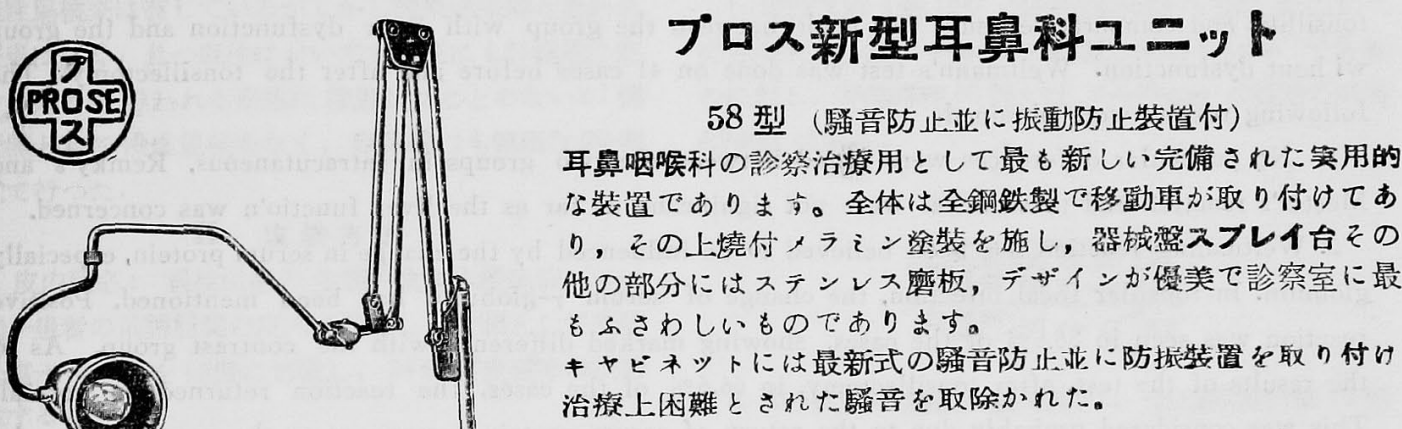

エニットの部品並に附属品 光源用伸縮自在電圢（笠前部は防熱硝 子付)

楽品旗（新案開閉蓋付） 13 個

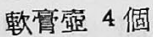
粉末噴霧 1 個 瓶型ネブシイザー 1 個 アトミザー 5 個 コンプレツサ直結へン ドル付スプレイー3個 (新案特許)

（詳しいバンフ

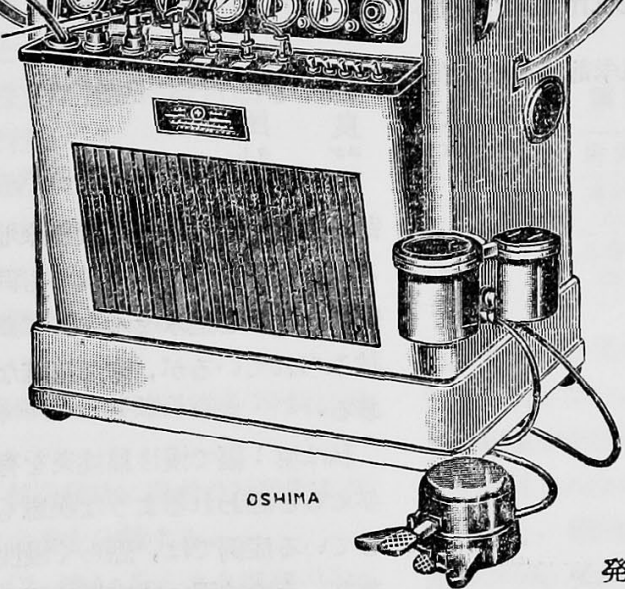
果京都京区駒込東片町一二三番地・電話小石川(92)一九五O・四六九 レットは申迈 次第野送致し ます)

発売製造元 株式大自社医科器械占

欧氏管通用耳管昛力メータ一 鼓膜按摩器 (小型モーター) ネブライザー（俚力調節器付） 医縮タンク压カメータ一付（吸引使 用中にてるスプレイ使用可能，電動 幾 2 台の能率ある)

電照 焼灼

活物入，吸引管薬液洗涤容器

電動ボンプ 日立1/1吸引，圷力の機能 を有す

鼻洗濟装量:楽液の酸化に耐ゆる班瑯 引使用容量 $5 \boldsymbol{l}$. 自動温度調節器付 自働仕力スイッチ足踏スイッチ 